\title{
BRACHIAL ARTERY DAMAGE ACCOMPANYING CLOSED POSTERIOR DISLOCATION OF THE ELBOW
}

\author{
R. J. GRIMER, S. BROOKS
}

\author{
From the Royal Orthopaedic Hospital, Birmingham
}

\begin{abstract}
Four cases of arterial damage resulting from closed posterior dislocation of the elbow are described. Two of these have been successfully treated by conservative methods and two by vein graft to the damaged artery. Sixteen previous cases are detailed and the management of this uncommon complication of dislocated elbow is discussed.
\end{abstract}

Dislocation of the elbow is relatively common; only the shoulder joint dislocates more frequently (Linscheid and Wheeler 1965). The majority of elbow dislocations are closed and posterior, but a small percentage are either anterior dislocations or open injuries. When the dislocation is open, vascular injury generally occurs (Kerin 1969; Mains and Freeark 1975); with closed injuries, however, especially in the absence of an accompanying fracture, it is rare. The English literature has fully detailed only 10 cases of vascular injury accompanying closed posterior dislocation without fracture (Table I), although a further six have been briefly mentioned by Linscheid and Wheeler (1965). There are considerable differences of opinion as to the best management of the combined injury. We describe a further four cases and discuss their management.

\section{CASE HISTORIES}

Case 1. A 28-year-old man sustained a closed posterior dislocation of his right elbow while playing football. He was seen in the casualty department within 20 minutes of the accident and radiographs confirmed the diagnosis (Fig. 1). The radial pulse was absent and the dislocation was reduced immediately under intravenous sedation with diazepam. The radial pulse did not reappear but the hand remained warm and movements were unimpaired. Paraesthesia was noted at the tips of the radial three digits. Over the ensuing hours considerable swelling and bruising appeared around the right elbow, but the radial pulse remained absent; after four hours it could, however, be detected with the aid of a Doppler ultrasound probe.

Twenty-four hours later the elbow swelling was tense and the pulse was still detectable only with the Doppler probe. The sensory deficit remained unchanged and the circulation of the hand remained intact. An arteriogram was carried out by the transfemoral route and this revealed complete occlusion of the right brachial artery over a distance of approximately $5 \mathrm{~cm}$ (Fig. 2); there was an excellent collateral circula-

R. J. Grimer, FRCS, Senior Orthopaedic Registrar S. Brooks, FRCS, Senior Orthopaedic Registrar Royal Orthopaedic Hospital, Woodlands, Northfield, Birmingham B31 2AP, England.

(C) 1985 British Editorial Society of Bone and Joint Surgery $0301-620 \mathrm{X} / 85 / 3078 \$ 2.00$ tion visible around the elbow with rapid distal filling. In view of this, conservative management was continued and the patient was observed in hospital for five days. At discharge the pulse was still not palpable but the elbow swelling was subsiding. The elbow was splinted at a right angle for three weeks and, when reviewed at the end of that time, the radial pulse was palpable.

He returned to work as a french polisher six weeks after the injury and when seen two weeks later he had a range of elbow movements of 5 to 135 . The radial pulse was strong but the brachial pulse was absent. The paraesthesia of his fingers was subsiding.

Case 2. A 31-year-old man, while under the influence of alcohol, fell from a ladder and sustained a closed posterior dislocation of his left elbow. The elbow was grossly swollen and there were symptoms and signs of irritation of the ulnar and median nerves. The radial pulse was absent but the capillary circulation of the hand was good.

After reduction the pulse remained absent but in view of the continuing good circulation to the hand he was observed but had no treatment. Over the ensuing week the symptoms of nerve irritation subsided but the pulse remained absent. He was treated by immobilisation of the elbow at a right angle for four weeks. When seen two months after the injury his elbow had a full range of movements, the nerve symptoms had subsided and the radial pulse could be felt, but was weak.

Case 3. A 36-year-old man presented with an injury to his right elbow, having fallen downstairs while under the influence of alcohol. He was noted to have a posterior dislocation of the elbow which reduced spontaneously while he was being transferred from stretcher to couch. Examination revealed a swollen elbow with bruising over the medial aspect. There were symptoms and signs of median nerve irritation and the radial pulse was absent, but there was good capillary return in the fingers.

Twelve hours after the injury a transfemoral arteriogram was performed which revealed a complete tear of the brachial artery. The elbow was explored and the findings of the arteriogram confirmed. There was also a large tear in the anterior capsule of the elbow joint, but the median nerve was intact. The artery was repaired with a vein graft. He made a satisfactory recovery, the median nerve symptoms subsiding and the elbow regaining a full range of movements.

Case 4. A 12-year-old boy fell from a rope swing and sustained a closed posterior dislocation of his right elbow. After reduction the radial pulse was noted to be absent although the peripheral circulation was intact. The elbow was explored the day after the accident; the brachial artery had been completely severed and there was a $7 \mathrm{~cm}$ gap. The gap was bridged with a cephalic vein graft and the radial pulse reappeared. When seen two months later he had a full range of movements at the elbow and normal radial and ulnar pulses. 
Table I. Summary of reported cases of arterial disruption resulting from closed posterior dislocation of the elbow

\begin{tabular}{|c|c|c|c|c|c|c|}
\hline Author & Year & $\begin{array}{l}\text { Age } \\
\text { (years) }\end{array}$ & Sex & Vessel involved & Treatment & Result \\
\hline Sherrill & 1913 & 23 & Male & Brachial & Direct suture & Satisfactory \\
\hline Marnham & 1934 & 40 & Female & Brachial & Ligation & Loss of 10 extension \\
\hline Eliason and Brown & 1937 & 20 & Male & Radial and ulnar & Ligation & Satisfactory \\
\hline Friedmann & 1961 & 36 & Male & Brachial & Direct suture & Satisfactory \\
\hline $\begin{array}{l}\text { Linscheid } \\
\text { and Wheeler }\end{array}$ & 1965 & \multicolumn{2}{|c|}{$\begin{array}{l}\text { No details } \\
\text { No details } \\
\text { No details } \\
\text { No details } \\
\text { No details } \\
\text { No details }\end{array}$} & $\begin{array}{l}\text { Brachial } \\
\text { Brachial } \\
\text { Brachial } \\
? \\
? \\
?\end{array}$ & $\begin{array}{l}\text { Ligation } \\
\text { Ligation } \\
\text { Repair } \\
\text { Observation } \\
\text { Observation } \\
\text { Observation }\end{array}$ & $\begin{array}{l}? \\
? \\
\text { Redislocation } \\
? \\
? \\
?\end{array}$ \\
\hline Aufranc et al. & 1966 & 50 & Male & Brachial & $\begin{array}{l}\text { Vein graft, } \\
\text { transarticular fixation }\end{array}$ & Loss of 20 extension \\
\hline Sullivan & 1971 & 32 & Male & Brachial & Vein graft & Satisfactory \\
\hline Louis et al. & 1974 & $\begin{array}{l}26 \\
61\end{array}$ & $\begin{array}{l}\text { Male } \\
\text { Female }\end{array}$ & $\begin{array}{l}\text { Brachial } \\
\text { Brachial }\end{array}$ & $\begin{array}{l}\text { Vein graft } \\
\text { Vein graft }\end{array}$ & $\begin{array}{l}\text { Loss of } 10 \text { extension } \\
\text { Graft thrombosis, swelling and claudication }\end{array}$ \\
\hline Peabody & 1978 & 12 & Male & Brachial & Vein graft & Satisfactory \\
\hline Sturm et al. & 1978 & 51 & Male & Brachial & $\begin{array}{l}\text { Vein graft, } \\
\text { transarticular fixation }\end{array}$ & Loss of 35 extension \\
\hline Grimer and Brooks & 1985 & $\begin{array}{l}28 \\
31 \\
36 \\
12\end{array}$ & $\begin{array}{l}\text { Male } \\
\text { Male } \\
\text { Male } \\
\text { Male }\end{array}$ & $\begin{array}{l}\text { Brachial } \\
\text { Brachial } \\
\text { Brachial } \\
\text { Brachial }\end{array}$ & $\begin{array}{l}\text { Observation } \\
\text { Observation } \\
\text { Vein graft } \\
\text { Vein graft }\end{array}$ & $\begin{array}{l}\text { Loss of } 10 \text { extension } \\
\text { Satisfactory } \\
\text { Satisfactory } \\
\text { Satisfactory }\end{array}$ \\
\hline
\end{tabular}

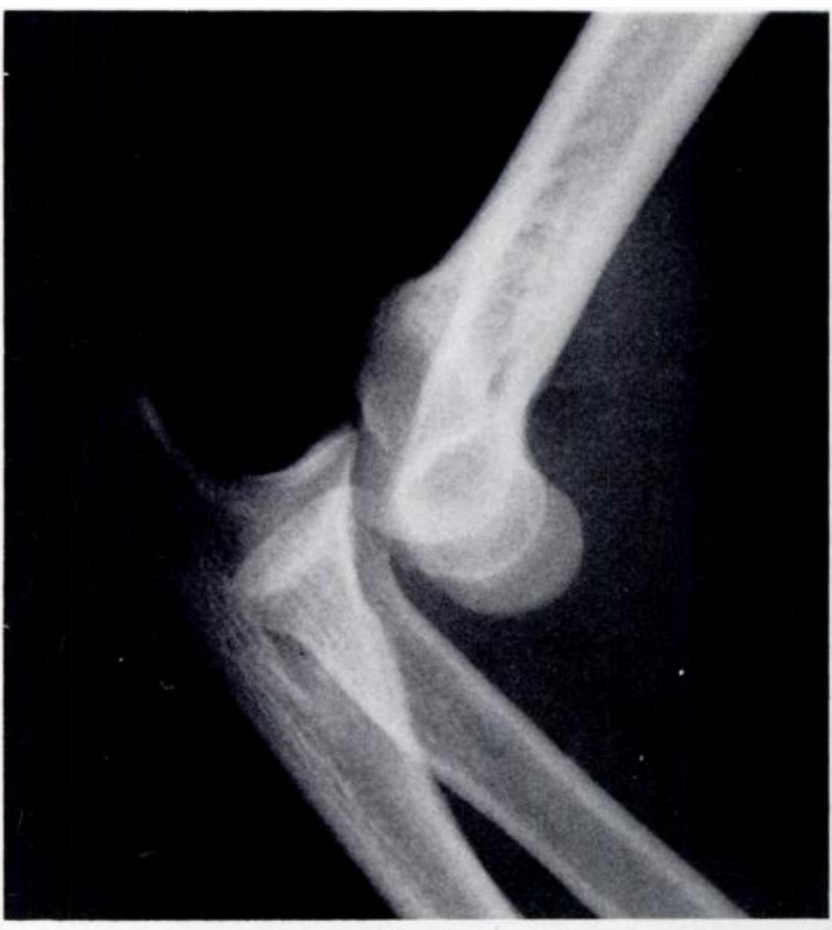

Fig. 1

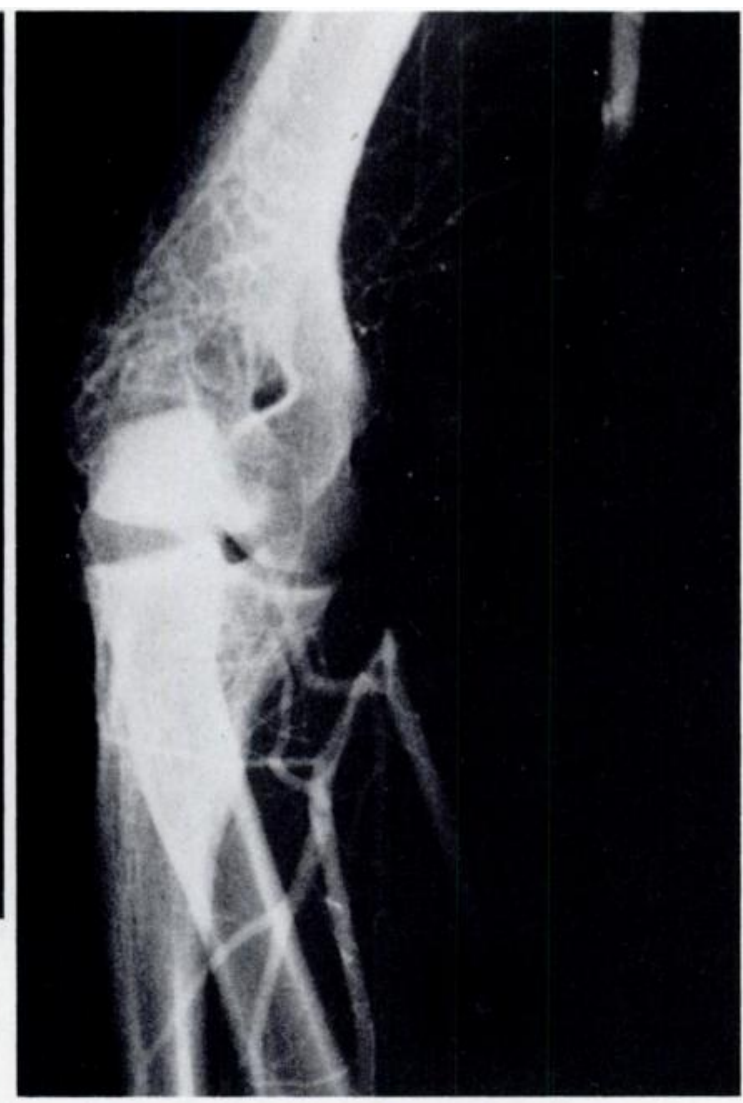

Fig. 2 


\section{DISCUSSION}

Sherrill (1913) was the first to report successful repair of the brachial artery after a closed posterior dislocation of the elbow. Eliason and Brown (1937), in a review of the literature, cited two cases which had resulted in gangrene and amputation, and a third which had resulted in Volkmann's contracture. Marnham (1934) had a successful result from direct ligation of the injured vessel; this technique was also used by Eliason and Brown in their one case (Table I) although in their patient it was the radial and ulnar arteries that were damaged rather than the brachial.

Linscheid and Wheeler (1965) described six cases of this complication occurring in 110 elbow dislocations over a period of 15 years; they did not, however, give precise details of the treatment or of the results. Aufranc, Jones and Turner (1966) described the first use of a vein graft in a case where the artery had thrombosed after direct suture. Louis, Ricciardi and Spengler (1974) used vein grafts for the repair but in one of their two patients the graft thrombosed and the patient was left with a persistently swollen forearm and symptoms of claudication. Sturm, Rothenberger and Strate (1978) recommended repair of the damaged artery with a vein graft, as well as transarticular fixation of the elbow to prevent redislocation and to protect the graft; this type of fixation was also used by Aufranc et al. (1966). It is perhaps significant that of all the cases mentioned these two had the least satisfactory functional results (Table I); this probably reflects the severity of the injury. In two of our cases treatment of the arterial damage has been expectant. Linscheid and Wheeler (1965) also comment on this form of treatment but do not report the final outcome.

Many authors (Friedmann 1961; Louis et al. 1974; • Mains and Freeark 1975; Sturm et al. 1978) have stated that arterial reconstruction is essential in every case of arterial disruption at the elbow, but our experience does not confirm this. A satisfactory outcome may be due to the fact that the arterial anastomosis around the elbow is profuse (Last 1978) and this may account for the good result obtained even after ligation of the artery (Eliason and Brown 1937).

Peabody (1978) reported the first case of a child with a brachial artery disruption accompanying a closed posterior dislocation of the elbow; our fourth case is, as far as we know, only the second child recorded in the English literature. Hofammann et al. (1984) reported a similar case but their child had an accompanying displaced fracture of the medial epicondyle. When there is a fracture in association with the dislocation, there appears to be an increased risk of vascular damage, probably because of the greater force involved in the original injury (Hennig and Franke 1980). Vascular damage in children is most frequently associated with supracondylar fractures of the humerus (Lipscomb and Burleson 1955; Laurence 1956).

Louis et al. (1974) have examined the integrity of the arterial collateral circulation in cadavers and found that forces sufficiently severe to cause dislocation of the elbow and disruption of the brachial artery were often severe enough also to damage the collateral circulation significantly. Friedmann (1961) also expressed this view and quotes figures from DeBakey which suggest that a quarter of patients with disruption of the brachial artery went on to lose the limb.

It would appear from our arteriogram (Fig. 2) that the collateral circulation is not always damaged and can be sufficient to maintain a viable and functional distal limb. Both our patients who were treated conservatively had considerable elbow swelling and bruising from the damaged artery and this swelling itself could have compressed the collateral circulation sufficiently to impair the flow of blood distally. The indication for surgery would then have been an inadequate distal circulation, when decompression of the elbow haematoma and ligation of the damaged vessel would have sufficed to restore the circulation through the collateral channels.

One reassuring feature about Case 1 was the ability, using the Doppler ultrasound probe, to detect a radial pulse within four hours of the accident. With this aid the presence of an adequate circulation could be assessed over the ensuing days. Peabody (1978) and Hofammann et al. (1984) also commented on the value of this technique; Hofammann also quotes the value of intravenous digital angiography in assessing the patency of the circulation at the elbow. In any case where the distal circulation is in doubt, as evidenced by more than one of the classic five criteria (pain, pallor, pulselessness, paraesthesiae and paralysis) then the artery should be explored (Ashbell, Kleinert and Kutz 1967).

Other indications for surgical intervention are to stabilise the dislocation, repair the damaged soft tissues, relieve the pressure on the median nerve and, finally, to prevent late claudication and intolerance to cold. Except in the most severe case of disruption it is unlikely that transarticular fixation or soft-tissue repair will produce a significantly better final result (Table I). Late claudication and cold intolerance are cited by Louis et al. (1974) and Mains and Freeark (1975) as reasons for surgical repair. Our first patient, who was treated conservatively, returned to work as a right-handed french polisher six weeks after injury to his right elbow and despite the nature of his job has had no symptoms of claudication.

Nerve symptoms are not uncommon after dislocations at the elbow. The ulnar nerve is more commonly affected in simple dislocations but, not surprisingly, it is the median nerve which is more commonly damaged when there is an injury to the adjacent brachial artery. Whether surgical decompression prevents the symptoms of nerve damage appearing or whether the damage is done at the time of the accident is not clear (Linscheid and Wheeler 1965). Three of our four patients had median nerve symptoms and one also had ulnar nerve 
symptoms; all symptoms subsided with expectant treatment.

It appears that there is probably a spectrum of damage which the arteries at the elbow may suffer after posterior dislocation of the elbow. At the worst there may be total disruption of the brachial artery and the collateral vessels. Alternatively the brachial artery alone may be damaged. In order to assess the extent of the damage an arteriogram is useful but not essential. If radial pulsation can be detected with the aid of the Doppler ultrasound probe a short time after injury and the perfusion of the hand is satisfactory, then surgery is not essential. If there is any question of ischaemia, excessive swelling at the elbow or a totally absent distal pulse, then surgical exploration is essential.

We would like to thank Mr D. J. C. Graff and Mr R. J. Cherry for permission to report cases under their care.

\section{REFERENCES}

Ashbell TS, Kleinert HE, Kutz JE. Vascular injuries about the elbow. Clin Orthop 1967;50:107-27.

Aufranc OE, Jones WN, Turner RH. Dislocation of the elbow with brachial artery injury. JAMA 1966;197:719-21.

Eliason EL, Brown RB. Posterior dislocation at the elbow with rupture of the radial and ulnar arteries. Ann Surg 1937;106:1111-5.

Friedmann E. Simple rupture of the brachial artery, sustained in elbow dislocation. JAMA 1961;177:208-9.
Hennig K, Franke D. Posterior displacement of the brachial artery following closed elbow dislocation. J Trauma 1980;20:96-8.

Hofammann KE III, Moneim MS, Omer GE, Ball WS. Brachial artery disruption following closed posterior elbow dislocation in a child: assessment with intravenous digital angiography: a case report with review of the literature. Clin Orthop 1984;184:145-9.

Jackson JA. Simple anterior dislocation of the elbow joint with rupture of the brachial artery: case report. Am J Surg 1940;47:479-86.

Kerin R. Elbow dislocation and its association with vascular disruption. J Bone Joint Surg [Am] 1969;51-A:756-8.

Last RJ. Anatomy: regional and applied. 6th ed. Edinburgh and London: Churchill Livingstone, 1978:84.

Laurence W. Supracondylar fractures of the humerus in children: a review of 100 cases. Br J Surg 1956;44:143-7.

Linscheid RL, Wheeler DK. Elbow dislocations. JAMA 1965; 194: $1171-6$.

Lipscomb PR, Burleson RJ. Vascular and neural complications in supracondylar fractures of the humerus in children. $J$ Bone Joint Surg $[\mathrm{Am}]$ 1955;37-A : 487-92.

Louis DS, Ricciardi JE, Spengler DM. Arterial injury: a complication of posterior elbow dislocation: a clinical and anatomical study. J Bone Joint Surg [Am] 1974;56-A:1631-6.

Mains DB, Freeark RJ. Report on compound dislocation of the elbow with entrapment of the brachial artery. Clin Orthop 1975; 106: $180-5$.

Marnham R. Dislocation of the elbow with rupture of the brachial artery. Br J Surg 1934;22:181.

Peabody CN. Rupture of the brachial artery in closed elbow dislocation: case report. Milit Med 1978;143:328-9.

Sherrill JG. Direct suture of the brachial artery following rupture, result of traumatism. Ann Surg 1913;58:534-6.

Sturm JT, Rothenberger DA, Strate RG. Brachial artery disruption following closed elbow dislocation. J Trauma 1978;18:364-6.

Sullivan MF. Rupture of the brachial artery from posterior dislocation of the elbow treated by vein-graft: a case report. Br J Surg 1971: 58:470-1. 